\title{
Hair Morphology Examination of Badger Meles Meles (L., 1758) in Turkey By Using Light And Scanning Electron Microscopes
}

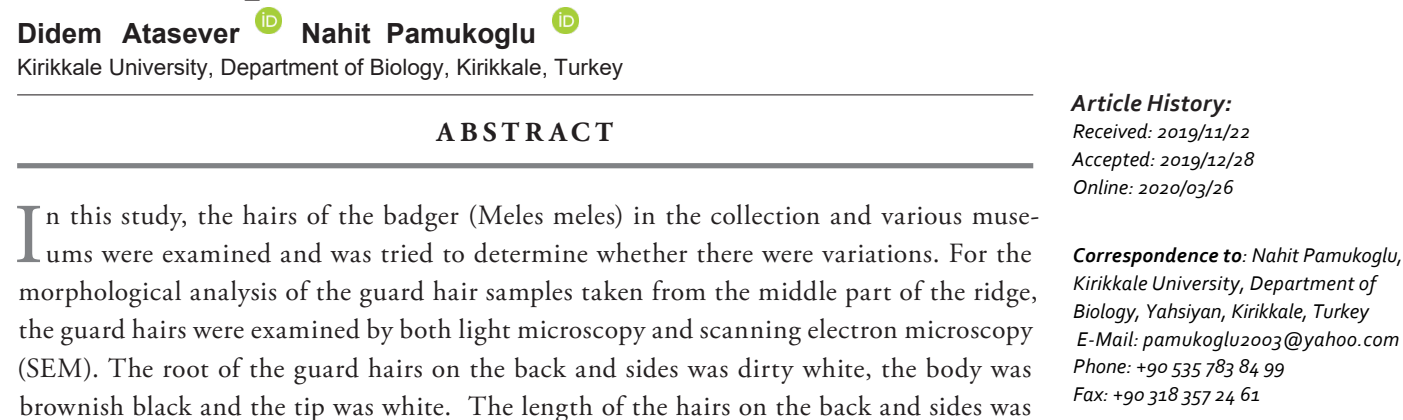
determined to be about $75 \mathrm{~mm}$. It was determined that 21 of the samples had summer fur, the dorsal part had brown and transition tones had dark brown hairs, and 4 had winter fur, the dorsal part had grayish brown hairs and the ventral part had blackish light brown hairs. In addition, winter fur was found to be covered more frequently and with long guard hairs.

Keywords:

Badger; Meles meles; Hair morphology; Turkey

\section{INTRODUCTION}

$\mathrm{O}$ ne of the factors that ensure the survival of mammals in the face of environmental changes is that their bodies are covered with hair [1]. Mammals have adapted to various environments with changes in their furs, which consist of various types of hair including protection and under fur hairs.

Carnivores naturally have hairs in digestive organs and stools and their location show little or no change and which give some informations about analysis of nutritional habits in animal ecology, wildlife biology and nature management. For these reasons, the first hair morphology studies were carried out by Tupinier [2], Kondo and Watanabe [3] and Kondo and Nishiumi [4] by using guard hair to be used as a key in order to identify the species. Then in 2003 Western European mammals by examining the structure of the differences between the species in terms of hair morphology was detaily reviwed by Teerink [5].

In Turkey, some researches were investigated by using hair morpohology to identify some species from different regions. For instance, Blackler [6] noted that the bottom of the bristles was whitish camel-haired and the rest was camel-haired. The researcher stated that approximately $1 / 3$ of the hair length near the tip was whitish with a black band and about $5 \mathrm{~mm}$ in length, and that fur gold was usually darker than camel hair (pale yellow) than long hairs.

Ognev [7] states that the maximum length of the guard hairs is about $50 \mathrm{~mm}$ in the middle of the rear; hair roots, dirty rusty straw white, black preterminal band, wider than winter fur and these bands started with mixed shades of cinnamon and the tip of the feathers, yellowish color and winter individuals less white color, snow in the abdomen rather sparse and bare skin in the abdomen and that the badger's summer fur is darker, blacker and more orange than winter fur.

Huş [8] and Erençin [9] claimed that the badger had hard thick hairs and the hairs on the abdomen were thin and sparse.

Turan [10] claimed that the guard hairs are long hard, the pile hairs are short and soft, the head and tail hairs are short and flat, the other parts are long and drooping, the skin is sparsely hairy enough to be seen in the abdomen.

Albayrak and Çoban [11] examined hair samples a total of 46 species belongs to Insectivora, Chiroptera, Lagomorpha, Rodentia, Carnivora and Artiodactyla orders morphologically. The researchers identified nine 
different types of guard hairs: vase, cone, fringed tail, mosaic, wavy serrated, wedge, irregular $\mathrm{V}$, baklawa and diamond pattern.

Özen and Uluçay [12] stated that the hairs on the dorsal part of all badger samples were longer. The researchers mentioned that the hairs were lying down in the direction of the ground. They claimed that the basal parts of the dorsal hair were white, the middle parts were mostly black and sometimes brown, and the most extreme parts were white.

Baydemir et al. [13] stated that general coloration of the guard hair is composed of three colours; black, rufous brown and creamy white. The structure of the hair scale was flattened imbricate and irregular crenate coronal at the base, shaft and the tip.

Pamukoğlu [14] found that the structure and some properties of the badger hair are different in terms of morphology and size when compared with other carnivore species. The researcher claimed that other carnivores were as short as hairy fur (skunk, weasel, otter and sea otter) and long haired fur (such as voracious animal and bear). The researcher also noted that some parts of badger fur are different from other carnivore species because of their coarse, sparse and heterogeneous appearance and having both short and long hair structure.

Pamukoğlu and Albayrak [15] stated that guard hairs are denser and longer in winter fur. Pamukoğlu and Tunçer [16] claimed that in a badger sample obtained from Çanakkale province, the hairs in the fur were short and the length of the guard hairs was approximately 45 and $60 \mathrm{~mm}$.

Demirbaş [17] found that the structure of the hair scale type was found to be "mosaic" at the proximal of the shaft, "elongate petal" at the distal of the shaft, "streaked" at the proximal of the shield, and "regular wave" at the distal of the shield. It was determined that there were not any variations in terms of hair morphology among the three analysed regions of Turkish hare populations.

The main purpose of this study is to determine whether the badger, Meles meles shows the hair variation by using with light microscope and SEM and doe the sybodyatic comparasion studies, the hair morphology of Meles meles with previous studies.

\section{MATERIAL AND METHODS}

For morphological analysis of guard hair samples taken from the middle part of the dorsum, the hairs were examined by both light and SEM [18, 19]. Hair samples were placed in a mixture of acetone, distilled acetone and dis- tilled water (1: 1 ratio) for 30 minutes and finally in distilled water for 10 minutes and dried. Morphological structures of the hairs were examined with light microscope (Leica DM5000 B, Leica Microsybodys Europe, Wetzlar, Germany) and SEM (JEOL, JSM 5600, Tokyo, Japan). Before SEM analysis, hair samples were stabilized on SEM stamps and were coated gold. Then images were taken in different parts of hair samples by both microscopes with different magnifications values.

\section{RESULTS}

\section{Hair Structure in Badger}

Microscopic examination of the hair color revealed that the two colors along the hair were transitions (shades of black and white). The hair is dominated by the white color from the root to the upper body, and after the upper body dark (black-brown) transition has been observed. The dark portion dominates the upper body and the lower region of the tip, and the color of the tip is observed to be white as you move to the upper part of the tip (Fig. $1)$.

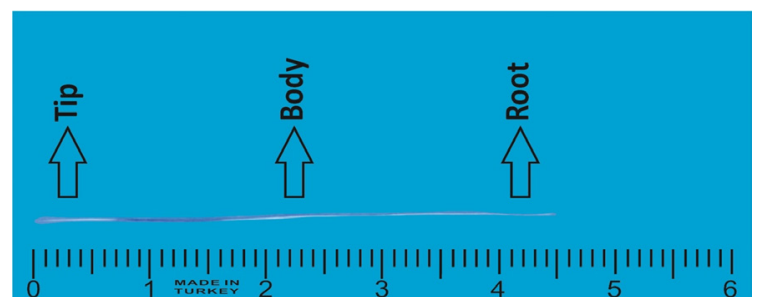

Figure 1. General structure of a guard hair examined in badger.

Different color regions were determined in the hair. The guard hairs were determined to have a 32-35 $\mathrm{mm}$ offwhite or straw-whitish basal portion followed by a 21-23 mm dark black band and a 9-11 mm long white or slightly grayish white tip. It was found that the base of the hairs on the side of the body was more dense. It has been observed that in adult individuals, the amount of graying increases in protection hairs compared to young individuals. The macroscopic examination of the hair in the badger revealed that the tip of the hair was white, the body was blackish dark brown, and the body to the root was white. In the adult samples, the increase in the white area of the protection hair was also observed. It has also been found that the hairs on the side form a fringed image. This can be used to distinguish adult individuals from young and offspring.

\section{Macroscopic Examination of Hair in Badger}

In microscopic examination of the hair sample taken from the dorsal part of the badger, the length of the hair from the tip to the lower tip point (white part) is $0.5 \mathrm{~cm}$, from the bottom point of the upper body (dark part) is 


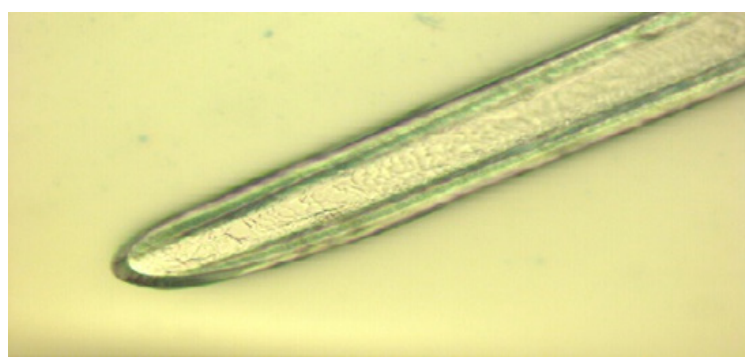

Figure 2. Examination of the tip of the hair at $50 \mu \mathrm{m}$ under a light microscope.

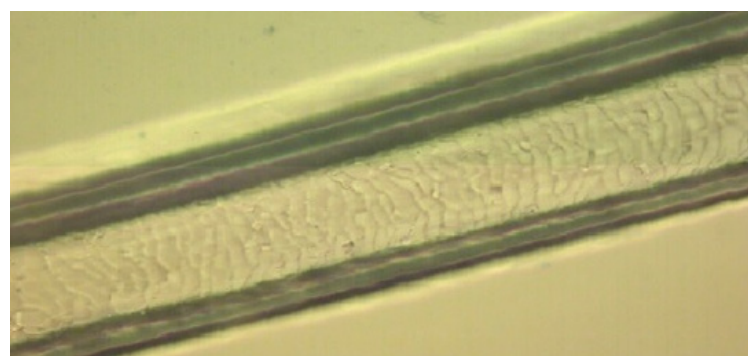

Figure 3. Examination of the body of the hair under a light microscope at $50 \mu \mathrm{m}$.

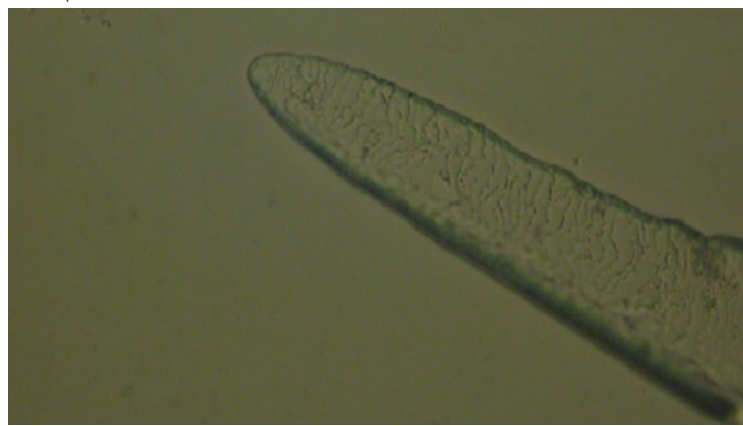

Figure 4. Examination of the root of the hair with a light microscope.

$1 \mathrm{~cm}$, from the upper body to the root (over skin) (white part) is $3 \mathrm{~cm}$ long. In other words, from the tip of the hair to the root (over skin), the length of the hair was found to be $4.5 \mathrm{~cm}$. Other protection hairs have been found to be about these dimensions.

\section{Examination of The Hair in The Badger By Using Light Microscope}

The light microscope examination of the hair showed thinning and fluctuations in the rough structure along the hair (Fig. 2, Fig. 3, Fig. 4).

\section{Investigation of Hair in Badger with SEM}

The root, the body and the tip of the hair were examined with SEM and images which were taken were illustrated in Fig. 5, Fig. 6 and Fig. 7. In SEM of the badger's guard hair, the examined hair grew by folding from the root and the width of the hair was narrower than the body at the tip and root. At X500 magnification, thickening was observed as the width of the hair at the root portion

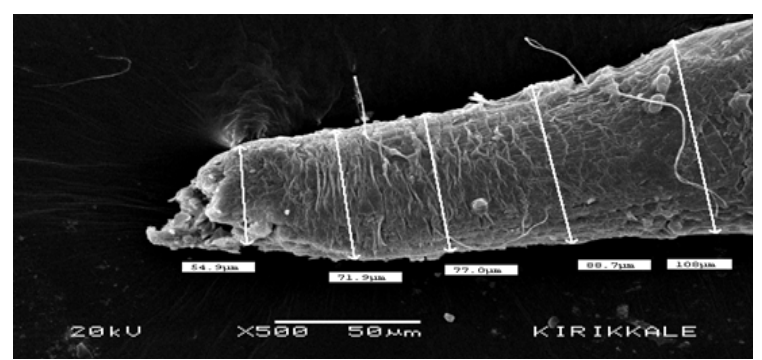

Figure 5. Thickening of the guard hair examined with SEM from the root to the body.

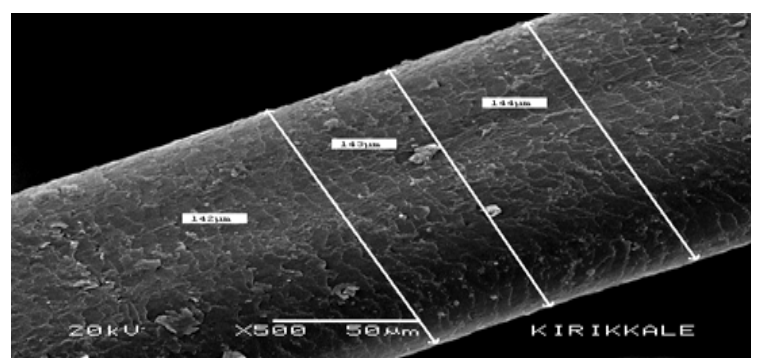

Figure 6. Continuous thickening of the body of the guard hair examined with SEM.

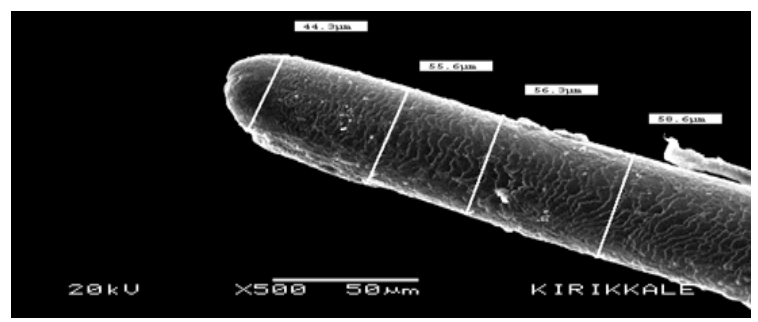

Figure 7. Narrowing of the tip of the guard hair examined with SEM.

of the hair progressed towards the body measuring 54.9 $\mu \mathrm{m} 71.9 \mu \mathrm{m}-77.0 \mu \mathrm{m}-88.7 \mu \mathrm{m}-108 \mu \mathrm{m}$. These thickening continued in the body as $142143 \mathrm{~m}-143 \mu \mathrm{m}-144 \mu \mathrm{m}$. But unlike the root and body as it reaches the tip of the hair, it is measured in the size of $58.6 \mu \mathrm{m}-56.3 \mu \mathrm{m}-55.6 \mu \mathrm{m}-44.3$ $\mu \mathrm{m}$ as it moves towards the of the hair.

\section{Profile of Guard Hair Examined with SEM}

The pieces in the cuticular layer at the tip of the hair are small and consist of smaller pieces than the root and the body (Fig. 8). The width of the pieces on the cuticular layer is higher than their length. In other words, the hair segments according to their longitudinal position are "transverse".

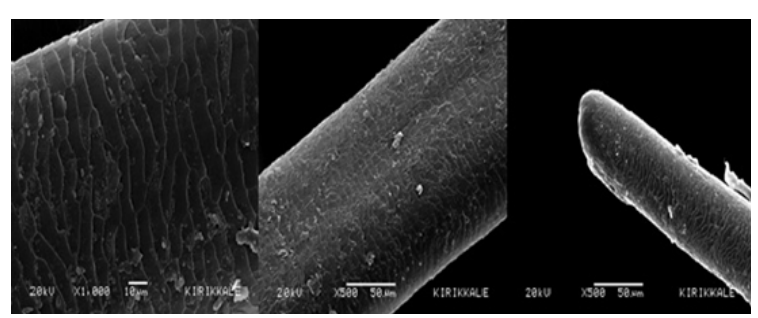

Figure 8. Thickening of the guard hair examined with SEM from the root to the body. 


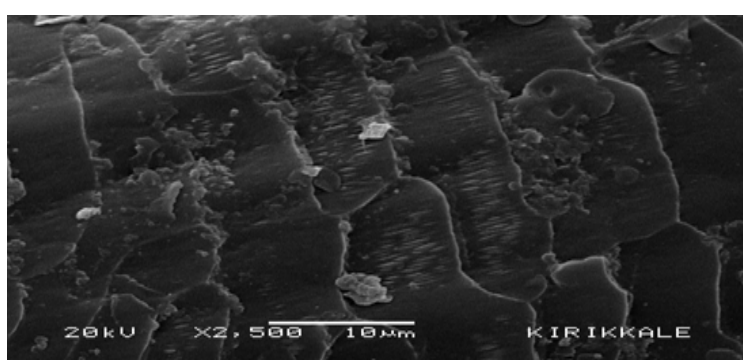

Figure 9. Diamond crown pattern view of the cuticular structure of the root portion of the hair examined with SEM.

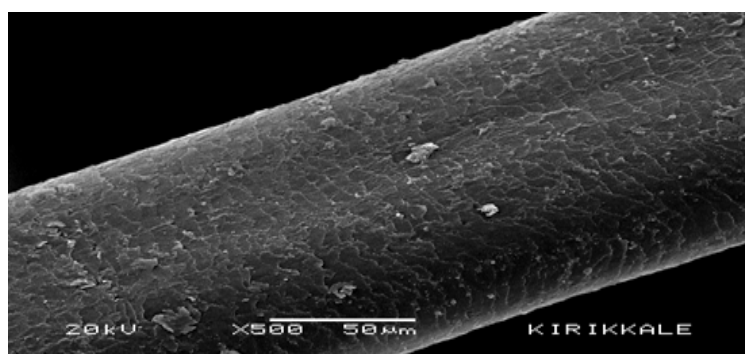

Figure 10. Diamond crown pattern of cuticular structure of the body part of hair examined with SEM.

It was seen that the cuticle structure was the diamond crown pattern (Fig. 9, Fig. 10). In addition, irregular wave pattern was found at the tip (Fig. 11).

The part margin structure on the root is "smooth". In other words, the margin is protruding. The part margin structure on the body and is "wrinkled" (Fig. 12, Fig. 13, Fig 14). So there are small indentations on the margin, and usually the distance between them is close.

The distance between the part margin is "close" pattern on the root, the body and the tip on a quantity basis.

\section{The Structure of Medullar in Cross Section of Guard Hair Examined in SEM.}

The medulla of the badger hair is more difficult to visualize than the cuticular structure. The medullary structure was examined by taking a cross section from the shield which is the thickest part of the hair (Fig. 15).

\section{Guard Hair Deformations Examined in SEM}

In some adult hair samples, SEM showed some deformed regions (Fig. 16, Fig. 17). Deformation was generally encountered in the tip and body parts of the hair and the body parts of hair was manifested in the form of tearing and irregular thickening-thinning, while the tip was directed towards breaking and bifurcation.

\section{DISCUSSION AND CONCLUSION}

It was found that the features indicated by some researc-

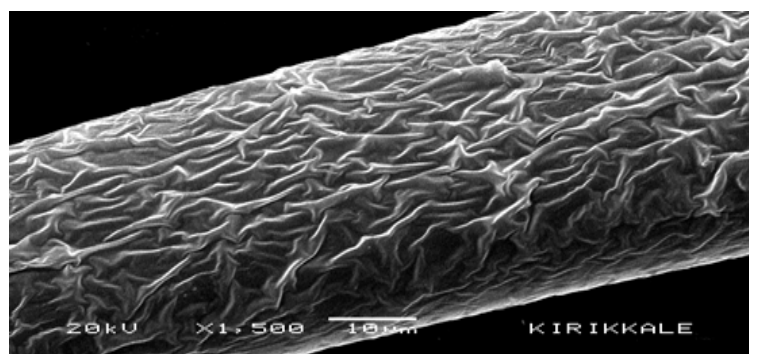

Figure 11. Irregular wave pattern of the cuticular structure of the tip of the hair examined with SEM.

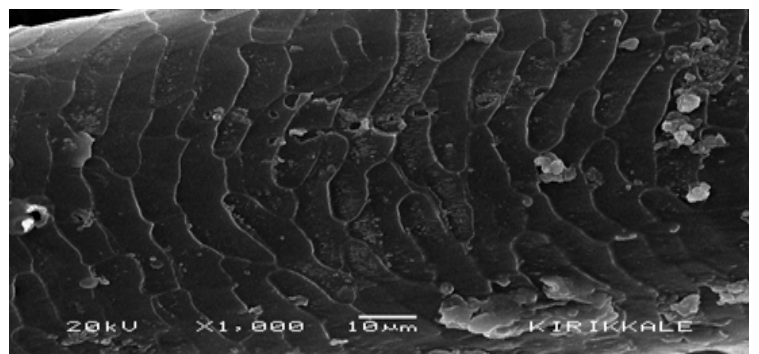

Figure 12. Smooth structure of the part margin of the root portion of the hair examined with SEM.

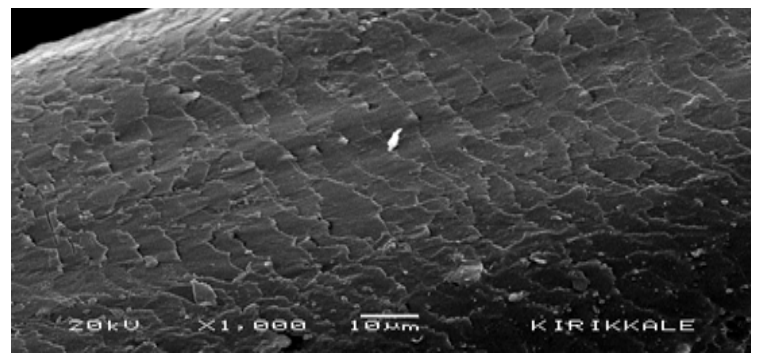

Figure 13. Wrinkled structure of the part margin of the body part of the hair examined with SEM.

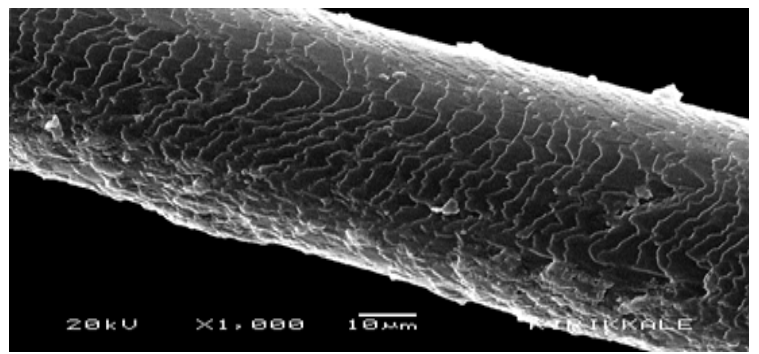

Figure 14. Wrinkled structure of the piece margin of the tip of the hair examined with SEM.

hers for instance Miller [20] and Ognev [7] almost coincided with our samples. In addition to the characteristics of Ognev [7], it was observed that the fur had longer hairs in the adult individuals among our samples and the age-related graying increased. As Huș $[8,21]$ stated, the hairs on the abdomen were thin and sparse and in addition, bare skin was seen due to sparse hairs. As Erençin [9] stated, our specimens were found to have frequent and hard hairs. Turan [10] stated that the long and drooping hairs on the side appeared as an age-related variation in our samples. Pamukoğlu [14], Özen and Uluçay [12], Pamukoğlu and Albayrak [15] were found to be similar to 


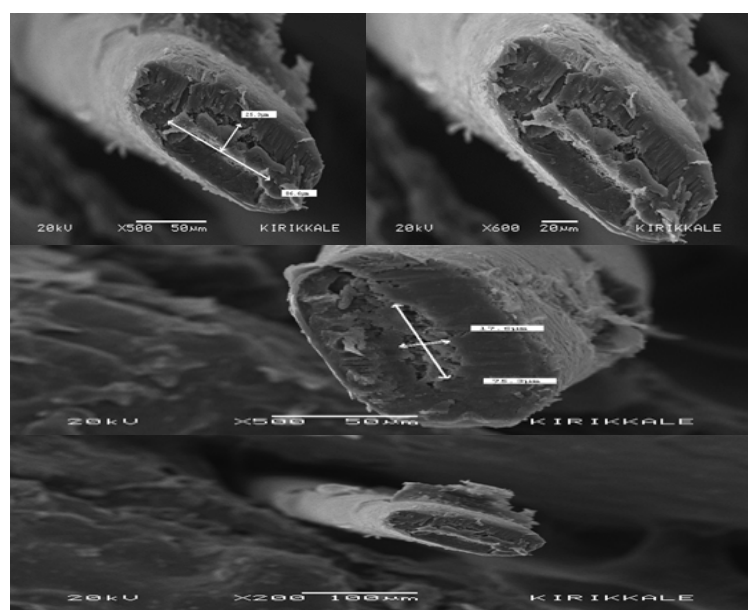

Figure 15. Medullary structure of hair examined with SEM.

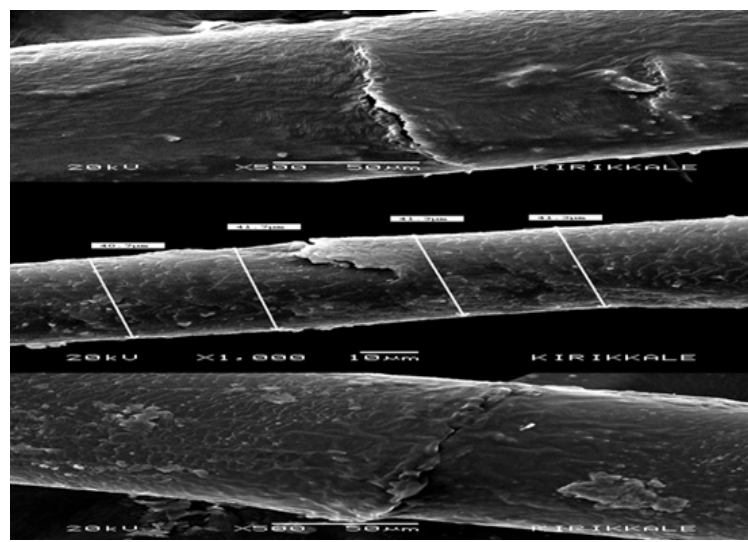

Figure 16. Bifurcation and fracture deformation of the tip of the hair.

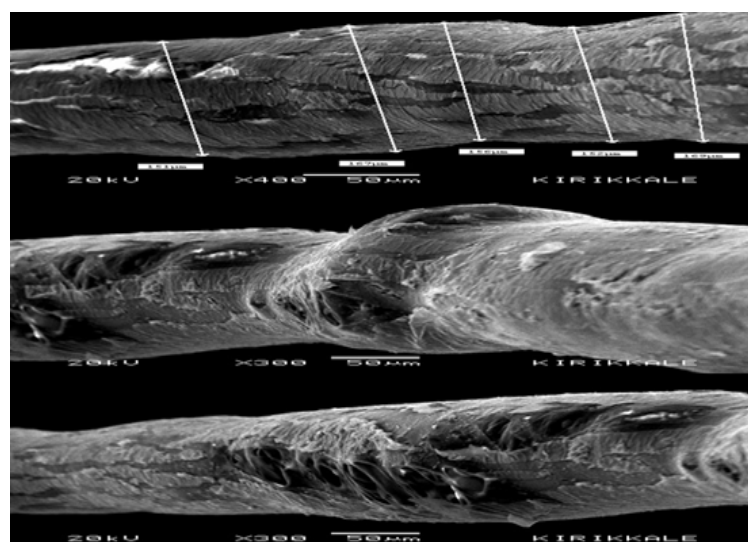

Figure 17. Tearing and irregular thickening-thinning deformation on the body part of the hair.

the results of our research.

The root of the guard hairs on the back and sides was dirty white, the body was brownish black and the tip was white. In particular, the hairs on the back and sides were found to be approximately $75 \mathrm{~mm}$ long. It was found that 21 of the samples had summer fur, the dorsal part consisted of brown and transitional hairs, the ventral part consisted of dark brown hairs, 4 of them had winter fur and the dorsal part had grayish color and the ventral part had blackish light brown tone. Winter fur was more often covered with long guard hairs.

It was observed that the part pattern was the diamond crown pattern as the cuticles in the protection bristles examined in the scanning electron microscope (SEM). In addition, irregular wave pattern was found at the tip.

It has been determined that the age of the individual, the decrease in the amount of keratin substance, climatic change and nutrition can cause deformations in the hair structure, and these deformations may occur in the form of tearing in the body of hair and bifurcation by breaking at the tip of hair.

\section{ACKNOWLEDGEMENT}

This study is a part of Didem ATASEVER's Master Thesis. We would like to thank Prof. Dr. Dinçer GÜLEN from Istanbul University Science Faculty and Asst. Prof. Dr. Oya ÖZULUĞ, who is responsible for the Zoology Museum of Biology Department and Prof. Dr. Tuğrul MOL, Istanbul University, Faculty of Forestry.

\section{References}

1. Kondo K. The Diversity of Mammalian Pelage. J. Fac.Agr. Hokkaido Univ., 2000;70 (1):9-17.

2. Tupinier Y. Morphologie des poils de Chiropteres d'Europe occidentale par etude du microscope electronique â balayage. Rev. Suisse Zool. 1973;80:635-53.

3. Kondo K, Watanabe F. The Identification to the hair Japanese Insectivora. 81st. Annual Meeting of Japanese Society of Zootechnical Ssience, 1989;85.

4. Kondo K, Nishiumi, T. The pelage development in young mink (Mustela vison). J. Fac.Agr. Hokkaido Univ. 1991;64 :247-255.

5. Teerink BJ. Hair of West European Mammals: Atlas And Identification Key. Cambridge University Press. First paperback edition 2003.

6. Blackler W. On Two New Carnivores From Asia Minor. Ann. Mag. Nat. Hist. 1916;18 (VIII):73 -77.

7. Ognev SI. Mammals of Eastern Europe and Northern Asia. Vol. 2, Carnivora, Fissipedia. Moscow, 1931.

8. Huş S. Av Hayvanları ve Avcılık, Kutulmuş Matbaası. İstanbul, 1967.

9. Erençin Z. Av Hayvanları ve Av. Ankara Üniversitesi Veteriner Fakültesi Yayınları. Ankara, 1977.

10. Turan N. Türkiye'nin Av ve Yaban Hayvanları (Memeliler). Ongun Matbaacılık Sanayii Ankara, 1984.

11. Albayrak İ, Çoban N. Hair Morphology Of Some Mammalian Species in Turkey. Communication Fas. Des. Scien. De L Univ. D-Ankara Series C, 1997; 15:21-39.

12. Özen AS, Uluçay İ. Kütahya İli Meles meles Linnaeus, 1758 (Mammalia: Carnivora)'in Bazı Ekolojik, Biyolojik ve Taksonomik Özellikleri. Dumlupınar Üniversitesi Fen Bilimleri Enstitüsü Dergisi, Kütahya, 2010;21:9-20.

13. Baydemir NA, Demirbaş Y, İliker A. Contributions To The Biology Of Wolves (Mammalia: Carnivora) İn Turkey. Internatıonal Journal Natural And Engineering Sciences 2011;5 (2): 33 -36.

14. Pamukoğlu N. 'Porsuk Meles meles (L., 1758)'de K1l Morfolojisinin 
İncelenmesi (Mammalia: Carnivora)". 22. Ulusal Biyoloji Kongresi, 23-27 Haziran 2014, Eskişehir Osmangazi Üniversitesi, Eskişehir, Türkiye. HB - Hayvan Biyolojisi (Sözlü Sunum), 2014;HB-S2-14:237.

15. Pamukoğlu N, Albayrak İ. The Taxonomy and Ecology of Meles Meles (L., 1758) in Western Turkey. Hacettepe J. Biol. \& Chem., 2014;42(4):451-458.

16. Pamukoğlu N, Tunçer S. Çanakkale İli Kepez Bölgesinde Porsuk Meles Meles (L., 1758) Üzerine Bir Araştırma. Tabiat ve İnsan Derg. 2014;3(3):17-21

17. Demirbaş Y. Studies on the Hair Characteristics of European Hare, Lepus europaeus (Lagomorpha: Leporidae) in Turkey. Pakistan J.
Zool., 2014;46(2):371-376.

18. Day MG. Identification of hair and feather remains in the gut and faeces stoats and weasels. J.Zool., London, 1966;155:458-497.

19. Hayat MA. Basic electron microscopy techniques. Van Nostrand Reinhold Company, New York, 1972.

20. Miller GS. Catalogue Of The Mammals Of Western Europe. British Museum Pub., London, 1912.

21. Huş S. Av Hayvanları ve Avcılık. İ.Ü.Orman Fakültesi Yayınları No: 1971. O.F. Yayın No: 202. İkinci Baskı. Kutulmuş Matbaası. İstanbul, 1974. 